\title{
Engaging Students with Visual Impairments or Blindness through Compre- hensive and Accessible Engineering Experiences
}

\section{Mrs. A. Leyf Peirce Starling, The Engineering Place, North Carolina State University}

Leyf Peirce Starling received a Bachelor of Science in Mechanical Engineering from the University of Virginia in 2003 and a Master of Arts in teaching with a focus on Special Education from UNC-Charlotte in 2010. She has teaching experience in both formal and informal educational settings. She has taught 6th, 7th and 8th grade math, science, social studies and reading comprehension and high school physics and aerospace engineering in North Carolina public and private schools. During the summers of 2013 and 2014, She served as the Academic Director for the Middle School Summer Math Camp and Middle School and High School Biosciences and Engineering Camps at Duke University. She has extensive experience in curriculum development as an editor for teachengineering.org and a lead developer for four Race to the Top courses on aerospace, automation and security. She has also served as a consultant for Michigan State's Research Experiences for Teachers program for the last three years. Currently, she is the Program Coordinator at the Engineering Place at North Carolina State University, where she also teaches an Introduction to Engineering course to incoming freshmen and lead the first ever Summer Engineering Experience for Students with Visual Impairments or Blindness at NC State University. She is also the Program Manager for the NSF funded Grand Challenges Themed Research Experience for Teachers program at NC State University.

\section{Mrs. Diane Brauner, Perkins School for the Blind}

Diane Brauner is an educational accessibility consultant currently collaborating with Perkins School for the Blind to create and manage the Paths to Technology - a website for educators to learn and stay current on technology for students with visual impairments and blindness (VIB). With the accessibility team at SAS, Diane has participated in a variety of assistive technology projects for students with (VIB) and to provide iPad accessibility trainings for teachers of students with VIB. Diane participated with the 2015 Summer Engineering Experience for Students with VIB. With 25 years experience as a Certified Orientation and Mobility instructor, Diane has taught primarily in the school setting with preschool and school age students with VIB. She holds degrees in Rehabilitation, Elementary Education, Visual Impairments, Hearing Impairments and Orientation and Mobility. 


\section{Engaging Students with Visual Impairments or Blindness through Comprehensive Accessible Engineering Experiences}

Introduction and program goals

In order to encourage diversity within the STEM fields, providing early opportunities for underrepresented students to engage in engineering remains a priority. Specifically, there is a need to increase the opportunities to educate and connect K-12 students with visual impairments or blindness (VIB) to STEM fields. A 2013 Disability Status Report ${ }^{1}$ surveyed 3,667,300 noninstitutionalized, working-age people reporting a visual disability to determine the highest level of education degree each had earned. Out of this population, $13.7 \%$ have earned a Bachelors degree or higher, $30.4 \%$ reported having some college experience and $31.9 \%$ indicated earning a high school diploma or GED. The lack of students with VIB attaining college degrees directly impacts the number of students with disabilities that go into STEM careers. Informal learning opportunities, such as summer camp experiences, provide students an opportunity to continue to grow and reinforce their interest in STEM. Previous K-12 summer engineering and science camps designed for the general education population yielded an improvement in student attitude towards science ${ }^{2}$. Additionally, data collected from previous camps designed to make science and robotics accessible to students with disabilities also demonstrated that these students increased their interest in science ${ }^{3,4}$. However, while a few science and robotics camps specifically for students with VIB have emerged in the past 5 years, little data has been published on the efficacy of these programs ${ }^{5}$. Therefore, it is essential to further explore engineering programs designed specifically to meet the needs of students with VIB. With minor modifications and implementations of assistive technology, exposing students with VIB to socially relevant, tactile engineering activities can provide further access to engineering concepts and career paths as well as effectively teaching math and science concepts.

The Summer Engineering Experience for High School Students with VIB at North Carolina State University (NCSU) aimed to engage participants in a week-long residential engineering experience on a college campus while also introducing transitional skills essential to success in a college environment. Specifically, the objectives were to engage students in the engineering design process to solve socially-relevant problems associated with the National Academy of Engineering Grand Challenges ${ }^{6}$ themes while incorporating opportunities for students to increase confidence levels in living independently, navigating dorm life and applying assistive technology tools to help navigate academic and non-academic activities. This program is one of the first engineering programs for students with VIB that was hosted on a college campus utilizing various spaces on campus including dormitories, engineering labs, dining halls, and campus public transportation. This paper outlines the program and analyzes preliminary data collected. As a "work in progress" with a small sample size and limited data, conclusions rely on few survey answers and anecdotal information. However, this paper explores possible replication models of this camp as well as implementation of these practices in school settings.

Team of Professionals

In order for the program to reach these goals, a team of 10 professionals in engineering, education, and teachers of the visually impaired or blind (TVIs) and orientation and mobility 
(O\&M) collaborated to develop, adapt, and implement engineering activities that would meet the needs of all students. Experts in the field of accessible technology also interacted with the students to instruct and guide students on using assistive technology appropriately. Each team member contributed a vital perspective to make this camp successful. Leyf Starling, an engineering educator and curriculum development specialist with over ten years of K-12 classroom experience, directed and organized the camp activities and lead the team of professionals. The science teacher provided additional instructional support during the implementation of the camp. The TVIs and O\&M supported the students in daily living and transitional skills. Additionally, one undergraduate education student and one graduate student studying biology provided insight on current strategies helpful to navigating college. The synergistic efforts of each team member contributed to being able to meet the needs of the students and provide them with an outstanding opportunity to explore engineering practices.

\section{Student application and selection process}

Four main criteria were used to select students in grades $10-12$ for this program. First, students had to have a documented visual impairment or blindness. Second, they had to show they were performing at or above grade level. This was verified by letters of recommendation from a current teacher. Third, the students needed to demonstrate an interest in pursing a STEM field, as expressed in short-essay answers. Fourth, students had to be independently mobile, i.e. be able to safely navigate a college campus with minimal guidance. To support students when they arrived on campus, the TVIs and O\&Ms provided an initial comprehensive orientation of the routes and buildings that the students would need to know, including dorms, classrooms, labs, and the dining hall. However, students were then expected to be able travel independently through campus. The solicitation for application to this program was posted on the hosting university's website. Additionally, the camp lead conducted two radio interviews and sent emails to school LEAs nationwide announcing the opportunity. Through this process, 21 students applied for the program, 12 were chosen based on the selection criteria and 9 attended.

Schedule and activities

In designing the schedule, the team aligned activities with themes of the Grand Challenges of Engineering, the steps in the engineering design process, and availability of lab tours and guest speakers as well as incorporating appropriate transition activities into the daily schedule.

Choosing appropriate activities tied into themes allowed for consistent reinforcement of not only the engineering design process, but also explicit instruction of science concepts. Following a successful Capstone Project model, the students concluded the camp by completing the engineering design process to solve a problem that they defined as socially relevant. Figure 1 provides a brief description of the activities completed in camp.

Pictures of campers doing sample activities:
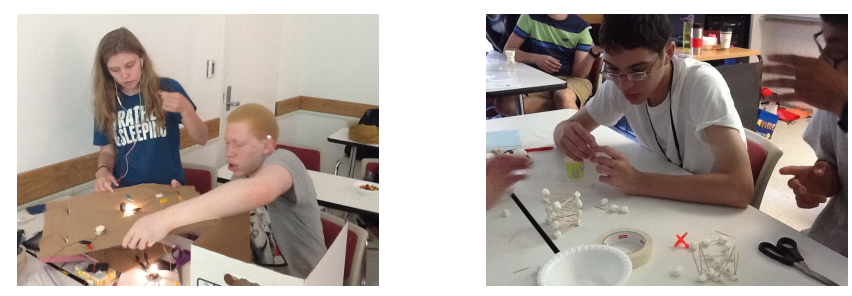
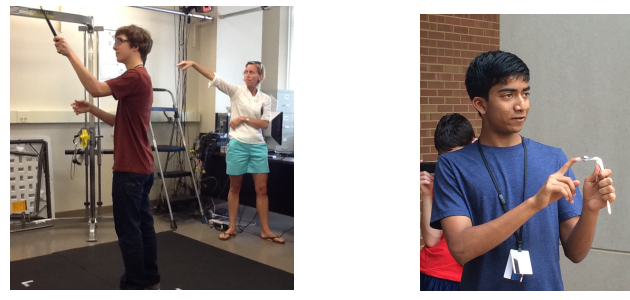
Figure 1: Camp Schedule and Activities

\begin{tabular}{|c|c|c|c|}
\hline Day & Theme & Activity & Description \\
\hline Sunday & $\begin{array}{l}\text { Orientation and } \\
\text { Introductions }\end{array}$ & $\begin{array}{l}\text { Move into } \\
\text { Dorms, } \\
\text { Orientation } \\
\text { and Mobility } \\
\text { Session, Camp } \\
\text { Overview } \\
\end{array}$ & $\begin{array}{l}\text { Students move into dorm rooms, work with } \\
\text { O\&Ms, meet camp staff and instructors, and } \\
\text { completed team building games to get to } \\
\text { know one another }\end{array}$ \\
\hline Monday & $\begin{array}{l}\text { Introduction to } \\
\text { Engineering; } \\
\text { Engineering } \\
\text { Design Process }\end{array}$ & $\begin{array}{l}\text { Educational } \\
\text { Toy }\end{array}$ & $\begin{array}{l}\text { Engineer an educational toy using scrap } \\
\text { material that will teach or test a } 2^{\text {nd }} \text { graders' } \\
\text { understanding of the engineering design } \\
\text { process }\end{array}$ \\
\hline $\begin{array}{l}\text { Monday/ } \\
\text { Tuesday }\end{array}$ & Sustainability & $\begin{array}{l}\text { Water Quality } \\
\text { Testing and } \\
\text { Water Towers }\end{array}$ & $\begin{array}{l}\text { Collect and analyze water samples from } \\
\text { local pond; engineer a water tower that will } \\
\text { cost the least, stand the tallest, and hold the } \\
\text { most water using only toothpicks and mini- } \\
\text { marshmallows for construction materials }\end{array}$ \\
\hline Tuesday & Sustainability & Solar Houses & $\begin{array}{l}\text { Using a cardboard box, wires, AA batteries } \\
\text { and battery packs, small solar panels, small } \\
\text { lights, buzzers, and motors, design and test } \\
\text { circuits to meet specific design constraints } \\
\text { while optimizing cost and materials }\end{array}$ \\
\hline Wednesday & Health & $\begin{array}{l}\text { Biomedical } \\
\text { Engineering } \\
\text { (BME) Guest } \\
\text { Speakers and } \\
\text { Lab Tour and } \\
\text { Activity }\end{array}$ & $\begin{array}{l}\text { Explore career paths in BME through } \\
\text { interactive discussions Engineering World } \\
\text { Health engineer and a BME faculty } \\
\text { member; tour BME lab and investigate } \\
\text { biomechanics using lab equipment to study } \\
\text { muscle/bone interaction; connect science } \\
\text { informing engineering design decisions }\end{array}$ \\
\hline Wednesday & Security & $\begin{array}{c}\text { Sound } \\
\text { Launchers }\end{array}$ & $\begin{array}{l}\text { Using popsicle sticks, rubber bands, tape, } \\
\text { and spoons, engineer a device that will } \\
\text { launch a small bell as far as possible }\end{array}$ \\
\hline Wednesday & $\begin{array}{l}\text { College } \\
\text { Transitional } \\
\quad \text { Skills }\end{array}$ & $\begin{array}{l}\text { Guest speaker } \\
\text { and library tour }\end{array}$ & $\begin{array}{l}\text { Discuss how to get into and survive an } \\
\text { engineering undergraduate program with a } \\
\text { graduate student with low vision; tour } \\
\text { library and learn of available resources for } \\
\text { accessibility }\end{array}$ \\
\hline $\begin{array}{l}\text { Thursday/ } \\
\text { Friday }\end{array}$ & $\begin{array}{c}\text { Engineering } \\
\text { Design Process }\end{array}$ & $\begin{array}{l}\text { Capstone } \\
\text { Project }\end{array}$ & $\begin{array}{l}\text { Design teams chose a grand challenge } \\
\text { theme and defined, analyzed, and proposed } \\
\text { a solution to the problem; teams prepared } \\
\text { formal presentations that was presented at } \\
\text { the end of camp to parents, engineering } \\
\text { faculty, and professionals invited to } \\
\text { presentations }\end{array}$ \\
\hline
\end{tabular}




\section{Tech time-outs}

Integrated throughout the program, the TVI and O\&M facilitated "Tech Time-Outs". This time provided opportunities to introduce or review necessary assistive technology. Some of these tech time-outs were in response to individual needs, and the TVI or O\&M would work one-on-one with the student to implement the technology, while other tech time-outs introduced a tool that would benefit the entire group. For example, students were introduced to a screen-sharing app (Join.me) that enabled each student to view materials being displayed on the whiteboard directly on his/her own computer or tablet. The student could then access this material using his/her device's preferred built-in magnification and low vision features. A personal, portable document camera (iZiggy) connected directly to an iPad was used to significantly magnify materials in order for students to independently work with wires and circuit boards for the solar project and to observe their team members while they worked with the circuit boards. Additional high and low tech devices were used throughout the college experience both in class and out of class. These tech time-outs further facilitated students' participation in open discussions about assistive technology, and students were encouraged to advocate for their individual needs. Creating an open discussion environment further supported student confidence in this area.

\section{Analysis of preliminary data}

Students were surveyed at the end of the program. These surveys were designed to assess the students' ability to define engineering, the engineering design process, the grand challenges of engineering and their perceptions of the camp. This is a work in progress, recognizing this small sample size yielded limited data. Based on the students' responses to the questions requiring them to define engineering, the engineering design process, and the themes of the grand challenges, $100 \%$ of the students demonstrated they correctly answered these questions

Figure 2 indicates the results from the post surveys where the students were asked to indicate if they strongly agree, agree, disagree, or strongly disagree with the following statements. It should be noted that two of the participants started the camp expressing that they were very proficient in using assistive technology, thus a drastic improvement was not expected for item 3 below.

Figure 2: Data collected

\begin{tabular}{|c|l|c|}
\hline $\begin{array}{c}\text { Item } \\
\text { Number }\end{array}$ & \multicolumn{1}{|c|}{ Question } & $\%$ Strongly Agree or Agree \\
\hline 1 & $\begin{array}{l}\text { This camp broadened my understanding of what } \\
\text { engineers do. }\end{array}$ & $100 \%$ \\
\hline 2 & $\begin{array}{l}\text { The camp taught me more about transitioning to } \\
\text { college and my options for pursuing engineering. }\end{array}$ & $100 \%$ \\
\hline 3 & $\begin{array}{l}\text { I learned more about useful technology that I will } \\
\text { use in my future classes. }\end{array}$ & $71 \%$ \\
\hline
\end{tabular}

In addition to survey data collected, student anecdotes during the final presentations in the "Capstone Symposium" yielded positive feedback. During this time, students presented their 
capstone project ideas and described the design process they applied to generate their solution. For example, one team that focused on the Health theme of the grand challenges, further defined, analyzed and posed a solution to the problem of applying eye drops. All three members of the design team had low vision and light sensitivity, and they determined a common problem is effectively applying eye drop medication. After researching existing solutions to help brainstorming possible new solutions, the team designed a prototype pair of sunglasses with a hole the same size as an eye-dropper. As a result of this project, the novel design currently has a provisional patent. While students practiced their technical communication skills during their presentations, they also expressed their thoughts about the camp. A local news channel filmed parts of this symposium and interviewed some of the students. One camper said, "Sometimes you feel like you are the only visually impaired person out there, but there's a lot of people out there who are also trying to do the same stuff and have the same interests as you"7. Clearly, the effects of the camp extended beyond the academic instruction by creating a community of young aspiring engineers. As a result of connections made through this camp, one of the students is blogging about assistive technology for students with VIB on the Paths To Technology website.

\section{Possible implications for further implementations}

This VIB program proved successful in three main areas. First, the academic focus engaged high school students with VIB in engineering activities on a college campus. The participating students applied the engineering design process, connected engineering to science and math, focused on the themes of the grand challenges, and experienced an engineering research laboratory. These activities exposed students to a variety of fields of engineering as well as common practices in engineering. Second, the transition to college focus provided students the opportunity to live in campus dorms, interact with undergraduate and graduate students with disabilities, and acquire accessible technology skills helpful in navigating a college campus and classes. This transition focus provided additional support to increase student confidence in applying for a college program. Third, this camp facilitated networking within the VIB community and between these students and potential mentors. Through interacting with graduate students with VIB, engineering faculty and local engineering professionals, the students were able to gain a better understanding of potential STEM career paths.

While the pilot program proved successful based on anecdotal information, additional data needs to be collected utilizing more comprehensive assessments. We plan on incorporating more assessments to inform the efficacy of this program and inform needed improvement for future programs. Additionally, there are two potential ways to disseminate lessons learned from this pilot program. First, the team plans to host a similar program for students with VIB in the summer of 2016. In order to improve this experience, based on student feedback, more laboratory tours will be scheduled so students can gain a better understanding of academic engineering research. Second, we would like to take the activities adapted for the camp into high school science classrooms. By requiring students to apply what they are learning in science to solve a socially relevant problem, students must synthesize and analyze the science concepts. Combined appropriate use of accessible technology with multisensory learning and assessment opportunities allows with VIB to access STEM fields more readily. Therefore, it is essential that these types of engineering activities be further incorporated into science classrooms as they make the material accessible to all students. 


\section{Bibliography}

1. Erickson, W., C. Lee, and S. von Shcrader. "Disability Statistics from the 2013 American Community Survey (ACS).” 2015 [cited 2015 January 26]; Available from: http://www.disabilitystatistics.org.

2. Bottomley, L., et al., Engineering Summer Programs: A Strategic Model Paper presented at 2015 ASEE Annual Conference and Exposition. Seattle, Washington., 2015(June): p. 10.18260/p.23982.

3. Napper, S.A., P.N. Hale, and F.J. Puckett, Motivating Students with Disabilities to Prepare for SEM Careers. Journal of Engineering Education, 2002. 91(3): p. 361-65.

4. Wedler, H.B., et al., Nobody can see atoms: science camps highlighting approaches for making chemistry accessible to blind and visually impaired students. Journal of Chemical Education, 2014. 91: p. 188-194.

5. Ludi, S. and T. Reichlmayr, The use of robots to promote computing to pre-college students with visual impairments. ACM Transactions on Computing Education, 2011. 11(3): p. Article 20.

6. Engineering, N.A.o. Grand Challenges of Engineering Homepage. 2015 [cited 2016 March]; Available from: http://www.engineeringchallenges.org/.

7. http://www.twcnews.com/nc/triangle-sandhills/news/2015/07/24/ncsu-hosting-engineering-camp-for-visuallyimpaired.html 